\title{
Appraisal of SOx Emission from Flue Gas in Thermal Power Station and Dry Sorbent Injection (DSI) Method to Reduce SOx
}

\author{
A. Mani , Justin Jagadeep Kumar
}

\begin{abstract}
Electrical vitality created in any nation is one of the advancement estimates happens in that nation. The vitality delivered is principally founded on the accessible assets, for example, streaming water, coal, oil, gas, atomic fills, wind, sunlight based and so forth.

The accessibility of wealth coal in India had incited the influence plant organizers to introduce coal based warm influence stations. During the pre-autonomy and post-freedom period in mid fifties, the need was to produce control and consequently much consideration was not paid to the contamination perspective and this proceeded up to late seventies.

Most of intensity plants in India extending from not many $M W$ to $500 \mathrm{MW}$ or more are of pummeled fuel terminated boilers using low calorific, low coal sulfur, high debris content sub-bituminous coal. Because of consuming of the coal, discharges, for example, Particulate Matter (PM), Oxides of Sulfur (SOx) and Oxides of Nitrogen (NOx) aside from $\mathrm{CO}$, $\mathrm{CO}$ are diverted to the climate through the vent gas. The mindfulness made by contamination impact on the general public and the tremendous measure of disintegration exposed to the gear constrained the specialists to make contamination standards increasingly stringent.

In this paper, the methodology to reduce SOx from flue gas in an old lower capacity power station is discussed and the optimum and cost effective methodology adopted is Dry Sorbent Injection (DSI) by injecting sodium bicarbonate or sodium carbonate or trona in the flue gas path after furnace and before/after Air-preheater to remove $\mathrm{SO} 2 / \mathrm{SO} 3$ from the flue gas. The removed sulphate will be collected along with ash in ESP or Fabric Filter in a Bag house
\end{abstract}

Key words: Dry Sorbent Injection (DSI), Trona, Sodium carbonate, sodium bicarbonate, Air-preheater, ESP, Baghouse..

\section{INTRODUCTION}

In India seventy percent of the electricity is generated through fossil fuels like coal. Due to more burning of fossil fuels for power generation, high air pollution has been observed in flue gas emitted from thermal power plants.

The primary discharges from coal burning at warm power plants are Carbon dioxide (CO2), Nitrogen oxides (NOx), Sulfur oxides (SOx), Chlorofluoro carbons (CFCs), carbonaceous material (ash), and air-borne inorganic particles, for example, fly debris, otherwise called Suspended Particulate Matter (SPM) and other follow gas species (21). Around half of the complete SOx, $30 \%$ of all out NOx, and

Revised Manuscript Received on December 11, 2019

Dr.A.Mani, Professor, Department Of Civil Engineering,,Bharath Institution Of Higher Education And Research,TamilNadu, India Email: maniathi57@yahoo.in

Justin Jagadeep Kumar, Student,Department Of Civil Engineering,,Bharath Institution Of Higher Education And Research,TamilNadu, India Email: jecar@rediffmail.com
$8 \%$ of absolute PM2.5 outflows are ascribed to the vitality part, inside which coal TPPs are the greatest givers (IEA and IIASA, 2015)

Even though the emission norms have been mentioned for Particulate Matter (PM) by the MoEF, there were no emission norms for Oxides of Sulphur (SOx), Oxides of Nitrogen (NOx) and Mercury (Hg) before 2015.

Coal from Indian mines have high debris content (which adds to PM discharges), while imported coal from South Africa and Indonesia have high sulfur content. Expecting normal plant working conditions and ignition change factors from writing, CSTEP's investigation shows that so as to fulfill the guidelines, convergences of SOx should be diminished by $67-95 \%$, NOx by $41-95 \%$ and PM10 by $50-85 \%$.

\section{A. Effects Of Sox On Environment}

One of the key emissions from the power plants is SOx. SOx emissions result in acid rain, corrosion of buildings and structures, and deterioration of human health. SOx emissions depend directly on the sulphur content in the coal being used to fire a plant. Studies indicate that SOx emissions from imported coal are lower as compared to Indian coal. [1]-[5]

\section{B. Effects Of Combustion Of Coal In Thermal Power Plants And Process Industries}

The poisons transmitted from warm power plants depend to a great extent upon the fuel consumed, the heater structure, the overabundance air, and any extra gadgets used to lessen the discharges. At present, the main control gadget utilized in warm power plants in India is Electrostatic precipitator (ESP) to control the emanation of fly debris (SPM). $\mathrm{CO} 2$, $\mathrm{SO} 2$, nitric oxide (NO), sediment, and SPM emanations from every one of the warm (coal-terminated) control plants in India have been processed utilizing fundamental standards of burning. Expanding interest for power and reliance on petroleum products will concentrate later on advancements to diminish outflows of numerous contaminations. [6]-[10] At present scenario, FGD leads the way in reducing the SOx emission from the flue gas due to its efficiency to reduce SOx upto $99 \%$ from flue gas.. However for lower capacity and old thermal plants where space is a main constraint to install FGD system, the Dry Sorbent Injection (DSI) methodology is one of the optimum methodologies for reducing SOx from the flue gas.

\section{MEASUREMENTS AND DATA COLLECTION}


A. A. Indian Standard Method For Measurement Of So2

\section{IS : 11255 (Part 2):1985}

This standard prescribes the IPA-Thorin method for measurement of sulphur dioxide emissions. A gas sample is extracted from the sampling point in the stack. The acid mist, including sulphur trioxide, is separated from the sulphur dioxide and the sulphur dioxide fraction is measured by the barium thorin titration method (13)

\section{B. B. Sampling Train}

In this project work, we are going to study the SOx emission level of a thermal power plant in India after the implementation of new environmental norms. For this SOx emission data has been collected before the implementation of suitable methodology[11]-[15]

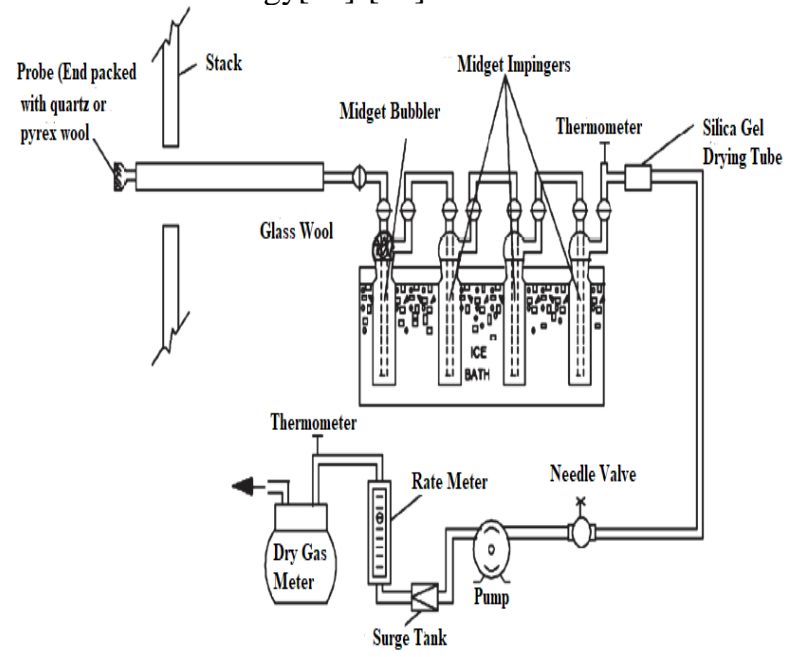

Fig. 1 sampling Train

Table I Initial readings taken in flue gas

\begin{tabular}{|c|c|c|c|c|c|}
\hline \multirow{2}{*}{ PASS } & \multirow{2}{*}{$\begin{array}{c}\text { Sample } \\
\text { No. }\end{array}$} & \multirow{2}{*}{$\begin{array}{c}\text { Stack } \\
\text { Temp. } \\
\left({ }^{\circ} \mathrm{C}\right)\end{array}$} & \multirow{2}{*}{$\begin{array}{c}\text { Velocity } \\
(\mathrm{m} / \mathrm{s})\end{array}$} & \multicolumn{2}{|c|}{ Actual Values } \\
\hline & & & & $\begin{array}{c}\mathrm{SO}_{2} \\
(\mathrm{mg} / \mathrm{Nm} 3)\end{array}$ & $\begin{array}{c}\text { Oxygen } \\
\text { as } 02 \\
\text { (\%) }\end{array}$ \\
\hline \multirow{2}{*}{ PASS A } & Sample I & 126 & 13.7 & 870 & 8.75 \\
\hline & Sample II & 127 & 14.2 & 898 & 8.46 \\
\hline \multirow{2}{*}{ PASS B } & $\begin{array}{l}\text { Sample } \\
\text { III }\end{array}$ & 129 & 14.4 & 913 & 8.68 \\
\hline & $\begin{array}{c}\text { Sample } \\
\text { IV }\end{array}$ & 127 & 14.0 & 928 & 8.52 \\
\hline
\end{tabular}

\section{Oxygen Corrections}

The results of SO2 has been compared with MoEF\&CC Emission Norms (2015) for Thermal Power Plants. It is observed that value of $\mathrm{SO}_{2}$ is exceeding the norms. The stack temperature is in the range of 126 to $129^{\circ} \mathrm{C}$ and the oxygen measured for the flue gas is in between 7.52 to $7.97 \%$ as can be seen from the data presented in the Table above
The excess air may be considered reason for dilution of flue gas and reducing the stack temperature $<135^{\circ} \mathrm{C}$. This low stack temperature causes condensation in exhaust duct line and stack. This may result into acid corrosion in flue gas path. There may be leakage from Air Pre Heater (APH) tubes, Electrostatic precipitator (ESP) - hopper bottom flange and multiple inspection window and fan inlet flange connection.

Hence Oxygen corrections are applied at $6 \% \mathrm{O}_{2}$ to the flue gas emissions for Sulphur Dioxide $\left(\mathrm{SO}_{2}\right)$ from the measured $\mathrm{O}_{2} \%$ by using CPCB Guidelines on Methodologies for Source Emission Monitoring, LATS/80/2013-2014. An amendment was issued vide GOI, MoEF \& CC Extraordinary Gazette dt. 29.06.2018. for $\mathrm{O}_{2}$ correction. The data of $\mathrm{SO}_{2}$ at measured $\mathrm{O}_{2}$ and calculated at $6 \% \mathrm{O}_{2}$.

Concentration values in $\mathrm{mg} / \mathrm{Nm} 3=$ Actual Concentration in $\mathrm{mg} / \mathrm{Nm} 3 \mathrm{x}[(21-\mathrm{Os}) /(21-\mathrm{Om})]$

(Corrected Values with $6 \% \mathrm{O}_{2}$ ),

Where,

Os = standard oxygen concentration $(6 \%)$

$\mathrm{Om}=$ measured oxygen concentration

\section{Readings After Oxygen Corrections}

Table II

Readings after oxygen correction

METHODS TO CONTROL SULPHUR EMISSIONS

$>$ Lower Sulfur Fuel

$>$ Dry Sorbent Injection

$>$ Dry Scrubber With Fabric Filter

$>$ Wet Scrubber

\begin{tabular}{|c|c|c|c|c|}
\hline \multirow[t]{2}{*}{ PASS } & \multirow[t]{2}{*}{ Sample No. } & \multirow[t]{2}{*}{$\begin{array}{c}\text { Stack } \\
\text { Temp. }\left({ }^{\circ} \mathrm{C}\right)\end{array}$} & \multirow[t]{2}{*}{$\begin{array}{c}\text { Velocity } \\
(\mathrm{m} / \mathrm{s})\end{array}$} & $\begin{array}{c}\text { Corrected } \\
\text { Values } \\
\text { with } 6 \% \\
\mathrm{O} 2\end{array}$ \\
\hline & & & & $\begin{array}{c}\mathrm{SO} 2 \\
(\mathrm{mg} / \mathrm{Nm} 3)\end{array}$ \\
\hline \multirow{2}{*}{ PASS A } & Sample I & 126 & 13.7 & 1065 \\
\hline & Sample II & 127 & 14.2 & 1074 \\
\hline \multirow{2}{*}{ PASS B } & Sample III & 129 & 14.4 & 1112 \\
\hline & Sample IV & 127 & 14.0 & 1115 \\
\hline
\end{tabular}

$>$ Limestone Injection

$>$ Wet Flue Gas Desulphurization

(1) Wet Limestone FGD

(2) Sea Water FGD

\section{CHOOSING THE RIGHT TECHNOLOGY}

\section{A. The Need For Dry Sorbent Injection (Dsi) Method}

According to an estimation made by CSE, the imported coal having 
$0.5 \%$ sulphur content with $\mathrm{NCV}$ of $5500 \mathrm{Kcal} / \mathrm{kg}$ generates about $950 \mathrm{mg} / \mathrm{Nm}^{3}$ of SO2, while Indian coal with $\mathrm{NCV}$ of $4100 \mathrm{Kcal} / \mathrm{kg}$ and sulphur content $\quad 0.5 \%$ generates about $1300 \mathrm{mg} / \mathrm{Nm}^{3}$. Even at $0.3 \%$ sulphur content, the SO2 emissions are estimated to be around $750 \mathrm{mg} / \mathrm{Nm}^{3}$ for Indian coal. The imported coal having sulphur content as high as $1.0 \%$ will have $1900 \mathrm{mg} / \mathrm{Nm}^{3}$.

However as per the standards notified by the MoEF \& CC in 2015 , the emissions need to be below $200 \mathrm{mg} / \mathrm{Nm}^{3}$ for units with $\quad 500 \mathrm{MW}$ or more capacity and below 600 $\mathrm{mg} / \mathrm{Nm}^{3}$ for units with less than $500 \mathrm{MW}$ of capacity. For new plants (commissioned after January 1, 2017), the SOx emission limit is only $100 \mathrm{mg} / \mathrm{Nm}^{3}$.

Since in our study, we have taken a 210 MW unit commissioned before 2003, the permissible SOx emission level should be below $600 \mathrm{mg} / \mathrm{Nm}^{3}$.

The challenge is to select the most appropriate technology, given the $\mathrm{t}$

depend on: the sulfur content of the coal being burned; the level of desulfurization required to meet regulations; the efficiency of the process, given that parasitic energy consumption varies from technology to technology; and, not least, the increasingly pressing issue of water usage, especially in arid areas or areas subject to drought.

Based on the above criteria, Dry Sorbent Injection (DSI) methodology has been adopted for reducing SOx level from flue gas in thermal power station with lower capacity.[16]-[19]

\section{KEY REQUIREMENTS FOR DSI SYSTEMS}

1. Moderate $\mathrm{SO} 2$ \& SO 3 removal

2. high reliability

3. saleable or usable by-product

4. almost no water consumption;

5. removal of $\mathrm{HCl}$ along with $\mathrm{SOx}$

6. requires less space

7. optimum for low capacity units

8. low investment cost

\section{PRINCIPLES OF DRY SORBENT INJECTION (DSI) METHOD}

The sodium carbonate or sodium bicarbonate (SBC) $\left[\mathrm{NaHCO}_{3}\right]$ or trona (Sodium sesqui carbonate) $\left[\mathrm{NaHCO}_{3}{ }^{\prime} \mathrm{Na}_{2} \mathrm{CO}_{3} 2 \mathrm{H}_{2} \mathrm{O}\right]$ is injected into the flue gas path either before or after Air preheater (APH) for the removal of $\mathrm{SO}_{2}$ and $\mathrm{SO}_{3}$.
In India most of the DSI system uses sodium bicarbonate (SBC) as sorbent due to its easy availability, low cost and high efficiency. The sorbent can be injected into several locations throughout the flue gas path, depending on preferred operation. Performance can vary based on mixing, injection location, and whether the station employs an electrostatic precipitator (ESP) or fabric filter (FF) as their particulate removal device.[25-34]

Normally, SBC sorbent was injected before the Air preheater (APH) to improve APH performance and reduce $\mathrm{H}_{2} \mathrm{SO}_{4}$ corrosion. With this type of DSI, the performance of APH can be improved, more heat will be returned to boiler and thus the boiler heat rate and efficiency will improve.

In some cases, injection was carried out after the air pre-heater and before the Electrostatic precipitator (ESP) or Fabric Filter (FF). This proved very effective at eliminating visible plumes at the stack.

SBC is the most available sodium sorbent for DSI. The material is delivered with a relatively large particle size to ease the handling and storage process. Therefore, it must be pulverized prior to injection in the flue gas path. For pulverizing/milling the SBC, different types of Mills are available according to the requirement, size and capacity of the power stations and the percentage of SOx to be removed.

Separate storage yard/silos are required for storing of SBC in a power plant. However Mobile DSI injection system is also available on temporary basis or for power stations with lower capacities.

Different capacity pulverizes were used specifically to achieve required size of the sorbent particle, increase the surface area. For this purpose blowers are used to convey the material from the silo through the mill to the duct.

While injecting the SBC sorbent, the flue gas temperature is very much essential since below $135^{\circ} \mathrm{C}$ the $\mathrm{SBC}$ will remain crystalline and above $345^{\circ} \mathrm{C}$, the $\mathrm{SBC}$ particles becomes soften, which reduces its porosity and therefore reactivity.

Therefore SBC should be injected in the flue gas zone where the temperature lies between $135^{\circ} \mathrm{C}$ and $345^{\circ} \mathrm{C}$ so as to achieve high level of SOx removal. (upto 60 to $70 \%$ ). However higher removal efficiency can be achieved if a Fabric filter is used instead of ESP in the system (upto 90\% SOx removal).

\section{EFFECT OF SORBENT AND PROCESS}




\section{PARAMETERS ON SO2 REMOVAL}

The $\mathrm{SO}_{2}$ removal in flue gas by DSI depends on the following parameters:

9. Sorbent type

- sorbent amount

- injection temperature

- temperature-time history

- sorbent surface area

- sorbent particle size

- initial SO2 level

- Particulate capture device.

\section{ABSORPTION PROCESS OF SO2 IN DSI USING SODIUM BICARBONATE}

Using Sodium bicarbonate in DSI enables a good removal result for $\mathrm{SO} 2$ at comparatively high temperatures and regardless of the flue gas humidity.

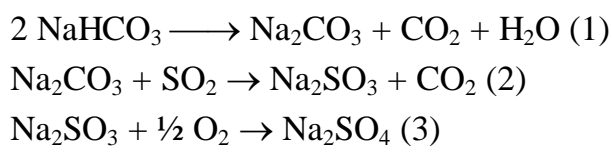

\section{MAJOR COMPONENTS OF DSI}

- Storage yard/Silo for storing sodium bicarbonate

- Mill for grinding sodium bicarbonate into fine particles

- Spraying system into flue gas duct (Before or after Air preheater)

\section{SCHEMATIC DIAGRAM OF DSI}

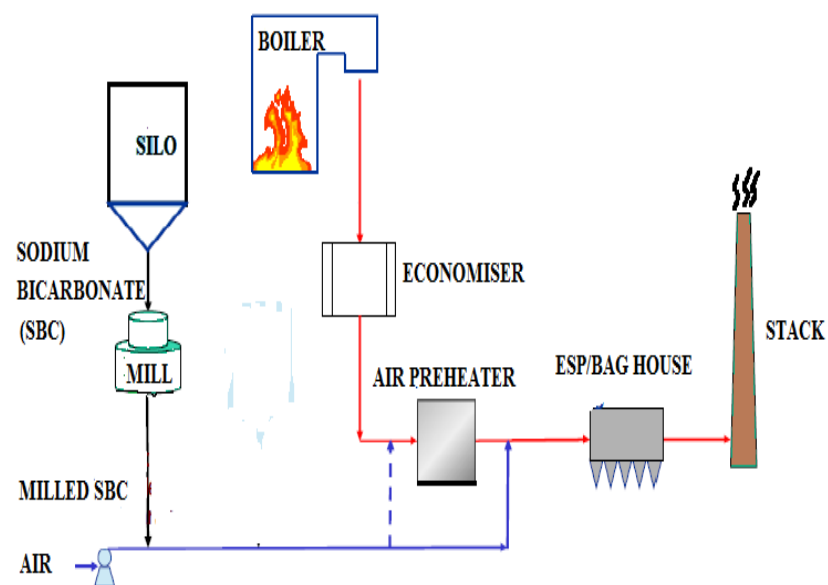

Fig. 2 Schematic diagram of DSI

\section{ADVANTAGES OF DRY SORBENT INJECTION}

(DSI)

- A dry sorbent injection (DSI) system enables plants to remain in operation when the capital cost of a wet or semi-dry flue gas desulphurization (FGD) system is too high. Injection of these alkali sorbents can also offer other benefits to the plant including lower operating costs, less corrosion and reduced activated carbon usage for mercury removal in high $\mathrm{SO}_{3}$ environments.

10.DSI is an easily retrofitted, low capital cost system that is capable of relatively high (upto 80 per cent) $\mathrm{SO}_{2}$ removal, especially with a fabric filter. DSI employs SBC, trona, or hydrated lime as sorbents of choice depending upon local availability and removal levels required. Operating costs of a DSI system have shown to be comparable to other FGD systems in the right application.

- Ideal solution for both coastal/hinterland locations

- Can be used for all fuels

- Low environmental impact

- Compliance with all legal emissions and discharge regulations

- Maximum plant availability at optimum overall system costs

- Energy-optimised plant operation thanks to flexible adaptation to the boiler operation

- Space-saving installation concept due to the concentric basin geometry

- Flexibility in narrow spaces

- Short construction time when compared with other types of FGD systems

- Simple \& reliable

- Proven Technology

- Uses only dry sorbents and no need for any additional water requirement in case of wet FGDs.

- No by-product handling

- Fully automated operation

\section{RESULT ANALYSIS}

\section{A. Final Measurements With Actual Oxygen Value}

The final measurements have been taken in the stack and tabulated as below:

Table III

Final Measurement of SOx

\begin{tabular}{|c|c|c|c|c|c|}
\hline \multirow{2}{*}{ PASS } & $\begin{array}{c}\text { Sample } \\
\text { No. }\end{array}$ & $\begin{array}{c}\text { Stack } \\
\text { Temp. } \\
\left({ }^{\circ} \mathrm{C}\right)\end{array}$ & $\begin{array}{c}\text { Velocit } \\
\text { y }\end{array}$ & & \multicolumn{2}{|c|}{ Actual Values } \\
\cline { 4 - 6 } & & $\begin{array}{c}\text { SO2 } \\
(\mathrm{mg} / \mathrm{Nm} 3)\end{array}$ & $\begin{array}{c}\text { Oxygen } \\
\text { as O2 } \\
(\%)\end{array}$ \\
\hline \multirow{2}{*}{ PASS A } & Sample I & 123 & 15.0 & 434 & 8.30 \\
\cline { 4 - 7 } & Sample II & 127 & 14.8 & 450 & 8.61 \\
\hline \multirow{2}{*}{ PASS B } & Sample III & 129 & 15.3 & 417 & 8.48 \\
\cline { 2 - 6 } & Sample IV & 127 & 14.5 & 428 & 8.83 \\
\hline
\end{tabular}




\section{Final Values After Oxygen Correction}

Oxygen corrections are applied at $6 \% \mathrm{O}_{2}$ to the flue gas emissions for Sulphur Dioxide $\left(\mathrm{SO}_{2}\right)$ from the measured $\mathrm{O}_{2} \%$ by using CPCB Guidelines on Methodologies for Source Emission Monitoring, LATS/80/2013-2014.

Table IV

Final Measurement of $\mathrm{SO}_{2}$ after oxygen correction

\begin{tabular}{|c|c|c|c|c|}
\hline \multirow{2}{*}{ PASS } & Sample No. & $\begin{array}{c}\text { Stack } \\
\text { Temp. } \\
\left({ }^{\circ} \mathrm{C}\right)\end{array}$ & $\begin{array}{c}\text { Velocity } \\
(\mathrm{m} / \mathrm{s})\end{array}$ & $\begin{array}{c}\text { Corrected } \\
\text { Values with } \\
6 \% \mathrm{O} 2\end{array}$ \\
\cline { 4 - 5 } & & $\begin{array}{c}\text { SO2 } \\
(\mathrm{mg} / \mathrm{Nm} 3)\end{array}$ \\
\hline \multirow{2}{*}{$\begin{array}{c}\text { PASS } \\
\text { A }\end{array}$} & Sample I & 135 & 15.0 & 513 \\
\cline { 4 - 5 } & Sample II & 137 & 14.8 & 545 \\
\hline \multirow{2}{*}{$\begin{array}{c}\text { PASS } \\
\text { B }\end{array}$} & Sample III & 142 & 15.3 & 523 \\
\cline { 2 - 5 } & Sample IV & 139 & 14.5 & 527 \\
\hline
\end{tabular}

\section{Comparing Effectiveness Of Dsi}

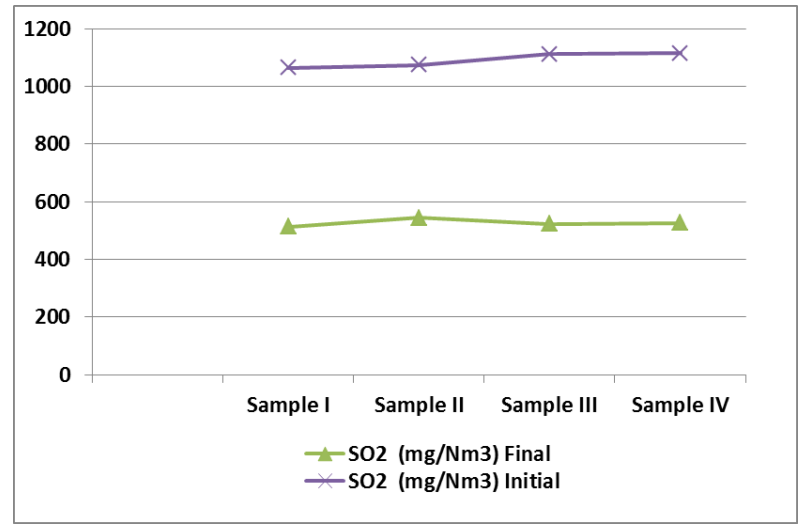

Fig. 3 SOx values before and after implementation of DSI

\section{REFERENCES}

1. Iyappan L., Dayakar P., Identification of landslide prone zone for coonoortalukusing spatial technology, International Journal of Applied Engineering Research,V-9,I-22,PP-5724-5732,Y-2014.

2. Kumar J., Sathish Kumar K., Dayakar P.,Effect of microsilica on high strength concrete, International Journal of Applied Engineering Research,V-9,I-22,PP-5427-5432,Y-2014.

3. Dayakar P., Vijay Ruthrapathi G., Prakesh J., Management of bio-medical waste, International Journal of Applied Engineering Research,V-9,I-22,PP-5518-5526,Y-2014.

4. Swaminathan N., Dayakar P., Resource optimization in construction project, International Journal of Applied Engineering Research,V-9,I-22,PP-5546-5551,Y-2014.

5. Venkat Raman K., Dayakar P., Raju K.V.B.,An experimental study on effect of cone diameters in penetration test on sandy soil, International Journal of Civil Engineering and Technology,V-8,I-8,PP-1581-1588,Y-2017.

6. Saritha B., Chockalingam M.P.,Photodradation of malachite green DYE using TIO2/activated carbon composite, International Journal of Civil Engineering and Technology,V-8,I-8,PP-156-163,Y-2017

7. Shendge R.B., Chockalingam M.P., Saritha B., Ambica A.,Swat modelling for sediment yield: A case study of Ujjani reservoir in

Maharashtra, India,International Journal of Civil Engineering and Technology,V-9,I-1,PP-245-252,Y-2018

8. Chockalingam M.P., Balamurgan V.,Modernisation of an existing urban road-sector in Chennai, a case study report,International Journal of Civil Engineering and Technology,V-8,I-8,PP-1457-1467,Y-2017

9. Saritha B., Chockalingam M.P.,Adsorption study on removal of basic dye by modified coconut shell adsorbent, International Journal of Civil Engineering and Technology,V-8,I-8,PP-1370-1374,Y-2017

10. Saritha B., Chockalingam M.P.,Adsorptive removal of heavy metal chromium from aqueous medium using modified natural adsorbent,International Journal of Civil Engineering and Technology,V-8,I-8,PP-1382-1387,Y-2017

11. Chockalingam M.P., Palanivelraja S.,Retrospective analysis of a theoretical model used for forecasting future air quality near the north Chennai thermal power plant,International Journal of Civil Engineering and Technology,V-8,I-8,PP-1457-1467,Y-2017

12. Saritha B., Chockalingam M.P.,Photodegradation of methylene blue dye in aqueous medium by $\mathrm{Fe}-\mathrm{AC} / \mathrm{TiO} 2$ Composite,Nature Environment and

Pollution

Technology,V-17,I-4,PP-1259-1265,Y-2018

13. Shendge R.B., Chockalingam M.P., Kaviya B., Ambica A.,Estimates of potential evapotranspiration rates by three methods in upper Bhima Basin, In Maharashtra, India,International Journal of Civil Engineering and Technology,V-9,I-2,PP-475-480,Y-2018

14. Shendge R.B., Chockalingam M.P.,The soil and water assessment tool for Ujjani Reservoir,International Journal of Mechanical Engineering and Technology,V-9,I-2,PP-354-359,Y-2018

15. Shendge R.B., Chockalingam M.P.,A review on soil and water assessment tool,International Journal of Mechanical Engineering and Technology,V-9,I-2,PP-347-353,Y-2018

16. Sachithanandam P., Meikandaan T.P., Srividya T.,Steel framed multi storey residential building analysis and design,International Journal of Applied Engineering Research,V-9,I-22,PP-5527-5529,Y-2014

17. Meikandaan T.P., Ramachandra Murthy A.,Study of damaged RC beams repaired by bonding of CFRP laminates,International Journal of Civil Engineering and Technology,V-8,I-2,PP-470-486,Y-2017

18. Meikandaan T.P., Ramachandra Murthy A.,Retrofittng of reinforced concrete beams using GFRP overlays,International Journal of Civil Engineering and Technology,V-8,I-2,PP-423-439,Y-2017

19. Meikandaan T.P., Ramachandra Murthy A.,Flexural behaviour of RC beam wrapped with GFRP sheets,International Journal of Civil Engineering and Technology,V-8,I-2,PP-452-469,Y-2017

20. Meikandaan T.P., Murthy A.R.,Experimental study on strengthening of rc beams using glass Fiber,International Journal of Civil Engineering and Technology,V-9,I-11,PP-959-965,Y-2018

21. Meikandaan T.P., Hemapriya M.,Use of glass FRP sheets as external flexural reinforcement in RCC Beam,International Journal of Civil Engineering and Technology,V-8,I-8,PP-1485-1501,Y-2017

22. Saraswathy R., Saritha B.,Planning of integrated satellite township at Thirumazhisai,International Journal of Applied Engineering Research,V-9,I-22,PP-5558-5560,Y-2014

23. Saritha B., Ilayaraja K., Eqyaabal Z.,Geo textiles and geo synthetics for soil reinforcement,International Journal of Applied Engineering Research,V-9,I-22,PP-5533-5536,Y-2014

24. Ambica A., Saritha B., Changring G., Singh N B., Rajen M., Salman Md.,Analysis of groundwater quality in and around Tambaram taluk, Kancheepuram district,International Journal of Civil Engineering and Technology,V-8,I-8,PP-1362-1369,Y-2017

25. Arunya A., Sarayu K., Ramachandra Murthy A., Iyer N.R.,Enhancement of durability properties of bioconcrete incorporated with nano silica,International Journal of Civil Engineering and Technology,V-8,I-8,PP-1388-1394,Y-2017

26. Ilayaraja K., Krishnamurthy R.R., Jayaprakash M., Velmurugan P.M., Muthuraj S.,Characterization of the 26 December 2004 tsunami deposits in Andaman Islands (Bay of Bengal, India),Environmental Earth Sciences, V-66,I-8,PP-2459-2476,Y-2012

27. Ilayaraja K.,Morphometric parameters of micro watershed in Paravanar sub-basin, Cuddalore District,International Journal of Civil Engineering and Technology,V-8,I-8,PP-1444-1449,Y-2017

28. Ilayaraja K., Singh R.K., Rana N., Chauhan R., Sutradhar N.,Site suitability assessment for residential areas in south Chennai region using remote sensing and GIS techniques,International Journal of Civil Engineering and Technology,V-8,I-8,PP-1468-1475,Y-2017

29. Ilayaraja K., Reza W., Kumar V., Paul S., Chowdhary R.,Estimation of land surface temperature of Chennai metropolitan area using Landsat images,International Journal of Civil Engineering and

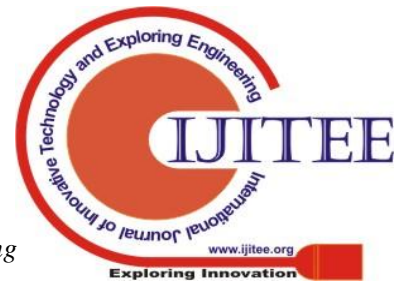




\section{Reduce SOx}

Technology,V-8,I-8,PP-1450-1456,Y-2017

30. Chitra R.,Experimental study on beam using steel fiber and latex,International Journal of Civil Engineering and Technology,V-8,I-8,PP-1395-1403,Y-2017

31. Chitra R.,Analysis of traffic and management at Kovilambakkam intersection,International Journal of Civil Engineering and Technology,V-8,I-8,PP-1433-1443,Y-2017

32. Aswathy M.,Experimental study on light weight foamed concrete,International Journal of Civil Engineering and Technology,V-8,I-8,PP-1404-1412,Y-2017

33. Aswathy M.,Wastewater treatment using constructed wetland with water lettuce (Eichornia Crasipies),International Journal of Civil Engineering and Technology,V-8,I-8,PP-1413-1421,Y-2017

34. Kiruthiga K., Anandh K.S., Gunasekaran K, Assessment of influencing factors on improving effectiveness and productivity of construction engineers, 2015, International Journal of Applied Engineering Research, V - 10,I -17,p -13849-13854.

\section{AUTHORS PROFILE}

Dr.A.Mani, Professor, Department Of Civil Engineering,,Bharath Institution Of Higher Education And Research,TamilNadu, India

Justin Jagadeep Kumar Student,Department Of Civil Engineering,,Bharath Institution Of Higher Education And Research,TamilNadu, India 